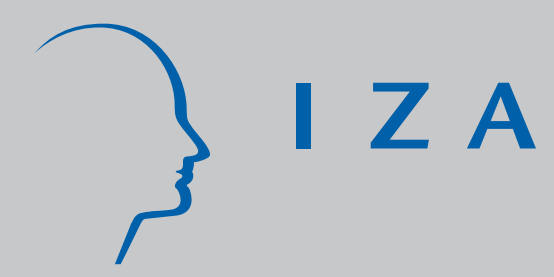

IZA DP No. 1134

What a Difference a $Y$ Makes -

Female and Male Nascent

Entrepreneurs in Germany

J oachim Wagner

May 2004 


\title{
What a Difference a Y Makes: Female and Male Nascent Entrepreneurs in Germany
}

\author{
Joachim Wagner \\ University of Lueneburg \\ and IZA Bonn
}

\section{Discussion Paper No. 1134 \\ May 2004}

\author{
IZA \\ P.O. Box 7240 \\ 53072 Bonn \\ Germany \\ Phone: +49-228-3894-0 \\ Fax: +49-228-3894-180 \\ Email: iza@iza.org
}

Any opinions expressed here are those of the author(s) and not those of the institute. Research disseminated by IZA may include views on policy, but the institute itself takes no institutional policy positions.

The Institute for the Study of Labor (IZA) in Bonn is a local and virtual international research center and a place of communication between science, politics and business. IZA is an independent nonprofit company supported by Deutsche Post World Net. The center is associated with the University of Bonn and offers a stimulating research environment through its research networks, research support, and visitors and doctoral programs. IZA engages in (i) original and internationally competitive research in all fields of labor economics, (ii) development of policy concepts, and (iii) dissemination of research results and concepts to the interested public.

IZA Discussion Papers often represent preliminary work and are circulated to encourage discussion. Citation of such a paper should account for its provisional character. A revised version may be available on the IZA website (www.iza.org) or directly from the author. 


\section{ABSTRACT \\ What a Difference a Y Makes: Female and Male Nascent Entrepreneurs in Germany*}

In western industrialized countries men are on average more than twice as active in entrepreneurship as women. Based on data from a recent representative survey of the adult population in Germany this paper uses an empirical model for the decision to become selfemployed to test for differences between women and men in the ceteris paribus impact of several characteristics and attitudes, taking the rare events nature of becoming an entrepreneur into account. Furthermore, a non-parametric approach using Mahalanobisdistance matching of man and woman which are as similar as possible in all characteristics and attitudes but the "small difference" is used to investigate the difference in the propensity to become self-employed by gender. A core finding is that the difference between men and women in both the extent and the effect of considering fear of failure to be a reason not to start one's own business is important for the explanation of the gender gap in entrepreneurship.

JEL Classification: J23

Keywords: nascent entrepreneurs, gender differences in entrepreneurship, Germany

Joachim Wagner

University of Lueneburg

Institute of Economics

21332 Lueneburg

Germany

Email:wagner@uni-lueneburg.de

\footnotetext{
* Research for this paper was done as part of the project Regional Entrepreneurship Monitor (REM) Germany financially supported by the German Research Foundation (DFG STE 628/7-1/2 and WA 610/2-1/2). I thank Uschi Backes-Gellner, René Leicht, Simon Parker, Friederike Welter and participants of the April 28, 2004, economics research seminar at the University of Lueneburg for comments on a draft version; the usual disclaimer applies. The title of the paper is, obviously, a tribute to Dinah Washington, who recorded the benchmark version of the Grever/Adams song "What a Diff'rence a Day Makes" back in 1959.
} 


\section{Motivation}

It is a stylized fact that in western industrialized countries the share of men in total selfemployment is much higher than the share of women (see OECD 2000, table 5.3). Recent empirical evidence based on millions of micro data from a large number of countries is given in Blanchflower (2004), who furthermore documents that the probability of preferring to be self-employed is higher for males compared to females, too. A major pattern found in the Global Entrepreneurship Monitor (GEM) is that men are on average more than twice as active in entrepreneurship as women (Reynolds et al. 2001, p. 15; Minniti and Arenius 2003); in 2002, the female share in total entrepreneurial activity in the 29 countries participating in GEM ranged from 44.3 percent in South Africa to 17.5 percent in Japan (Verheul, van Stel and Thurik 2004, Table 2).

Germany is a case in point. According to official statistics women's self-employment rate (percentage of all working women) is only about half of the men's rate - the figures are 5.0 percent and 10.3 percent for 1991, and 6.3 percent and 12.9 percent for 2002 (LauxenUlbrich and Leicht 2003, p. 15). According to a representative survey among the population (aged 18 to 64 years) in 10 German regions in 2001 the share of men who were actively involved in starting their own new business was 4.9 percent compared to 2.3 percent of all females (Bergmann, Japsen and Tamasy 2002, p. 15); similar results (4.70 and 2.27 percent, respectively) were obtained in the nationally representative sample for the German part of the Global Entrepreneurship Monitor 2002 (Sternberg and Bergmann 2003, p. 13). A survey of the Rhine-Westfalia Institute for Economic Research (RWI) showed that in 1999 in Germany 15.9 percent of all men, but only 7.4 percent of all women, wish to become self-employed (Welter and Lagemann 2003, p. 31).

In a sense this relationship between gender and self-employment is easier to understand than other relationships between entrepreneurship and individual characteristics or attitudes gender is stictly exogeneous because it does in no way depend on the choice between selfemployment and paid employment, so we can exclude that causality runs from selfemployment to gender. However, what about the other direction? Economists tend to be 
reluctant to put the blame for the choice between alternatives on a single chromosome. Individual characteristics (like age, endowment with human capital, or the profession of the father) and attitudes (like the degree of risk aversion) that are related to the (expected, discounted life-time) relative payoff of self-employment compared to paid employment are used by economists to explain the choice between these alternatives. How large is the part of the difference between men and women in the propensitiy to become self-employed that can be explained by differences in characteristics and attitudes - or, for short, "endowments"? And how large is the (unexplained) rest that is due to different "rates of return" to components of these endowments - differences that are due to the fact that women are women and not men?

Given the huge gender difference in self-employment reported above, and the widespread interest in political measures aimed at fostering female entrepreneurship, ${ }^{1}$ it comes as a surprise that the economic literature on this gender gap is rather small. As Simon Parker puts it in his recent comprehensive treatise on the economics of self-employment and entrepreneurship: "Despite its intrinsic interest and importance, the subject of female entrepreneurship has arguably not commanded the degree of research effort that it deserves. Little is known about precisely why there is less female than male entrepreneurship ..." (Parker 2004, p. 129). ${ }^{2}$ Again, Germany is a case in point. According to Lauxen-Ulbrich and Leicht (2003, p. 6), there is (at least in relation to other countries) a lack of gender-related data and research on business ownership and self-employment. ${ }^{3}$

\footnotetext{
${ }^{1}$ See OECD (2000, p. 183ff.) for a survey of self-employment policies for women. A case in point for Germany is the recently started initiative of the Federal Government to support women who are in the process of starting their own business. Three federal ministries finance a service agency (with 3.146 million Euro in 2004 - 2007) with the dedicated aim to increase the share of start-ups by women. See the press release 2004-03-05 by the Federal Ministry for Education and Research for details.

${ }^{2}$ For surveys of this literature, see Carter, Anderson and Shaw (2001), McManus (2001), and Parker (2004, p. 124 - 129).

${ }^{3}$ Lauxen-Ulbrich and Leicht (2003) present a collection of tables and figures for selfemployment and start-ups by gender in Germany. Welter and Lagemann (2003, chapter 3) give a descriptive comparison of male and female nascent entrepreneurs, while Fehrenbach and Lauxen-Ulbrich (2002) report descriptive evidence on differences of self-employed and employed men and women with regard to, inter alia, age, levels of schooling, and vocational
} 
This paper contributes to the economic entrepreneurship literature by reporting results of an econometric inquiry into the extant and the causes of differences between female and male nascent entrepreneurs. The data are taken from a recent representative survey of the adult population in Germany. Based on an empirical model, derived from a theoretical framework, the difference by gender in the propensity to step out of paid employment into self-employment is documented and investigated. Note that we do not consider the choice between working (in the market) or not here. This important omission is due to the fact that important variables influencing this participation decision (like age of youngest child in the household, presence of a spouse or other persons with own income, amount of earnings by a spouse or other persons, amount of income form other sources) are not available from the survey. Note further that so-called nascent entrepreneurs are investigated - people who are just about to start as self-employed (more on this below). By focussing on gender differences in the factors affecting the decision to become self-employed, as opposed to remaining in paid-employment, instead of looking at differences in the probability that males or females are self-employed rather than employees, we avoid confounding entry and survival effects: The probability of being self- employed at a point in time depends on the probability of switching into self-employment in the past and then surviving as a self-employed until the time of the survey (see Parker 2004, p. 25f.). To put it differently, while differences between males and females who were self-employed for some time are an important topic, too, it is not dealt with in this paper. ${ }^{4}$

education. Sternberg, Bergmann and Lückgen present descriptive evidence on differences between male and female nascent entrepreneurs and non-entrepreneurs. The ceteris paribus role of gender for being or starting to be self-employed is investigated with German micro data by Hübler (1991, 1992), Lechner and Pfeiffer (1993), Georgellis and Wall (2000), Linan Alcalde, Martin and Gonzales Rodriguez (2002), Wagner (2003a, 2003b, 2003c, 2003d, 2004), Wagner and Sternberg (2004, 2005), Engel and Welter (2004), and Bergmann (2004, chapter 6). The "state of the art" of research in female entrepreneurship in Germany is documented (unfortunately, in German) in two recent collective volumes edited by Leicht and Welter (2004) and by KfW Bankengruppe (2004).

${ }^{4}$ Carr (1996) uses data from the Census of Population and Housing to compare demographic and labor supply characteristics of male and female self-employed in the US in 1980, and she estimates two logistic regression models separately for men and women to investigate 
In the empirical investigation two approaches (described in detail in section 4 below) are used that, to the best of my knowledge, have not been applied in this context before: ${ }^{5}$

- An empirical model for the decision to become self-employed is used to test for differences between women and men in the ceteris paribus impact of several characteristics

differences in the determinants of self-employment by gender. Simpson and Sproule (1998) perform a similar analysis for Canadian male and female self-employed. Parker (2004, p. 128) reviews the empirical evidence of the under-performance of female self-employees relative to males in terms of income, output, employment, and turnover. Evidence for Germany on survival and success of newly founded firms by gender of the founder is given in JungbauerGans (1993); Wießner (2001) reports differences by gender in the post-entry performance of self-employed who were subsidized by a so-called "bridging allowance" when they founded their own firm out of unemployment.

5 Nancy Carter (1997) uses data from the Wisconsin Entrepreneurial Climate Study to compare selected characteristics of 58 male and 34 female nascents; Nancy Carter and Lars Kolvereid (1998) look at small samples of male and female nascent entrepreneurs from the United States and Norway. These comparisons, however, are only descriptive, and the decision to become a nascent entrepreneur or not is not dealt with. Gry Agnete Alsos and Elisabet Ljunggren (1998) look at data from a survey conducted in Sweden to investigate whether there are gender differences with regard to what nascent entrepreneurs do during their start-up processes, and they examine to which extent men and women who attempt to start a business succeed in actually doing so. Again, this is a purely descriptive study, and the decision to become a nascent entrepreneur or not is not looked at. Paul Reynolds (1997) looked at differences between female and male nascent entrepreneurs in the U.S. using stepwise logistic regressions with a gender dummy. Richard Boden (1996) - using US data - , Yannis Georgellis and Howard J. Wall (2000) - using German data -, Carol Moore and Richard Mueller (2002), and Kate Rybczynski (2004) - using data from Canada - , and Frederic Delmar and Per Davidsson - using data from Sweden - come closer to the first approach applied in this paper in estimating probit or logit models for the step into selfemployment separately for men and women. However, these authors do not test statistically for the significance of the differences in the estimated coefficients for males and females, and they ignore the rare event nature of switching from paid-employment to self-employment in applying the standard probit or logit model. Note that in the papers using German micro data by Hübler, Lechner and Pfeiffer, Linan Alcalde, Martin Martin and Gonzales Rodriguez, Wagner, Wagner and Sternberg, and Bergmann, listed in footnote 3 gender is only included as a dummy variable in the empirical models that explain (nascent) entrepreneurship. 
and attitudes, and the rare events nature of becoming an entrepreneur is explicitely taken into account when estimating this model.

- Furthermore, a non-parametric approach is applied based on a Mahalanobis-distance matching of man and woman that are as similar as possible in all characteristics and attitudes but the "small difference", and than looking at the difference in the propensity to become selfemployed between these groups of "twins".

The rest of the paper is organized as follows: Section 2 develops a theoretical framework for our investigation; section 3 introduces the survey data used and discusses the theoretical hypotheses and measurement issues; section 4 gives descriptive empirical information; section 5 introduces the empirical model and reports on the results of the econometric investigation; section 6 concludes.

\section{Theoretical framework}

To discuss the role of gender in the process of becoming a nascent entrepreneur consider a utility-maximizing individual that has the choice between paid employment and selfemployment. ${ }^{6}$ This person will choose the option self-employment if the discounted expected life-time utility from self-employment (DELUs) is higher than that from paid employment (DELUp). The difference Ni between DELUsi and DELUpi,

(1) $\mathrm{Ni}=$ DELUsi - DELUpi

therefore, is crucial for the decision of individual $\mathrm{i}$, and it will choose self-employment if $\mathrm{Ni}$ is positive.

\footnotetext{
${ }^{6}$ Remember that the decision to participate in the market is taken as given.
} 
DELUsi and DELUpi are determined by the expected monetary and non-monetary returns from self-employment and paid employment according to the utility function of the person and the individual's discount rate. Higher returns lead to higher values of DELU.

The expected monetary and non-monetary returns from both types of employment depend on variables that can be considered as endowments of individual i (like age, a university degree, or the degree of risk-aversion) summarized in the vector xi. Given that $\mathrm{Ni}$ depends on DELUsi and DELUpi, and DELUsi and DELUpi depend on the monetary and non-monetary returns, Ni can be written as a function of xi:

(2) $\mathrm{Ni}=\mathrm{Ni}(\mathrm{xi})$

Individual endowments (elements of xi) which have a more positive or less negative impact on DELUsi than on DELUpi increase Ni (and vice versa). Given that the expected monetary and non-monetary returns from both types of employment, the utility function, and the discount rate of an individual are unknown to an observer, we cannot observe Ni. Therefore, we cannot test directly whether an individual characteristic or attitude - say, a university degree, or a high degree of risk aversion - has a positive impact on Ni or not. If, however, $\mathrm{Ni}$ is greater than the critical value zero, according to our theoretical framework a person will choose to become an entrepreneur, and the decision to do so or not is observable. In our empirical model we will investigate the influence of the elements of xi on the probability that a person becomes an entrepreneur by looking at his known decision pro or contra.

The theoretical hypotheses regarding a positive or negative influence of personal characteristics and attitudes on this decision are discussed below in section 3 together with a description of the way the elements of xi are measured. Given that details of the specification of the empirical model are (as usual) data driven, we will turn to a description of the data base used in our study before. 


\section{Data and theoretical hypotheses}

The data used in this paper are taken from a representative survey of the population aged 18 to 64 in 11 (out of 97) so-called planning regions in Germany that was conducted using computer assisted telephone interviewing by TNS EMNID, a leading opinion research institute, between June and August 2003. This survey is part of the research project Regional Entrepreneurship Monitor (REM) Germany 2003 which focuses on the extent of the difference in entrepreneurial activities between regions in Germany, its determinants, and its consequences for regional development. ${ }^{7}$ The data set contains information on 12.000 people. ${ }^{8}$ The questionnaire asked for socio-demographic characteristics (e.g., sex, age, employment status, education, fields of professional experience) and a number of items related to entrepreneurial activities (e. g., whether the interviewee is currently engaged in starting an own business). ${ }^{9}$

In the empirical model discussed in the next section we regress the observed decision whether to start a new business or not on a variable indicating the gender of a person, and on a set of personal characteristics and attitudes. Selection of the elements included in the empirical model are, at least in part, data driven. Although we had full control over the design of the questionnaire used in the REM survey, we were unable to collect information on all individual characteristics that are important for the decision under consideration due to budget constraints (that limited the time per interview and the number of items to be included) and the willingness of the interviewees to report information on issues like the amount of personal

\footnotetext{
${ }^{7}$ For further information about the REM project see Bergmann et al. (2002). REM is closely related to GEM, the Global Entrepreneurship Monitor, a multi-country study that investigates the same topics at a national level (see Reynolds et al. 2000).

${ }^{8}$ The data will be made available for public scientific use after the completion of the REM project.

${ }^{9}$ An English version of the questionnaire is not yet available; a German version is available from the author on request.
} 
wealth. Effects of variables not included in the empirical mode ${ }^{10}$ are covered by the error term. Frankly, this might lead to an omitted variables bias - a problem common to many (all?) econometric investigations.

That said, we will now turn to a discussion of the variables that are included in our empirical model.

In the survey the interviewee was asked whether she/he is (alone or with others) actively involved in starting a new business that will (as a whole or in part) belong to her/him, and whether this business did not pay full time wages or salaries for more than three months to anybody (including the interviewee). Those who answered in the affirmative are considered to be nascent entrepreneurs. ${ }^{11}$ Interviewees who are currently working in a private sector firm and who are not nascent entrepreneurs are considered to be employees. The empirical model considers the decision between these two alternatives only; self-employed, public sector employees, and people out of the labor force are excluded from the sample.

As regards the individual characteristics and attitudes, the empirical model includes the following variables:

- Age (measured in years). Hypothesis: On the one hand, age is a proxy variable for personal wealth - the older a person is, the longer is the potential period to accumulate wealth. Given that young firms are often constrained by lack of credit because banks usually demand collateral to finance investments, a certain amount of wealth is crucial for starting a new business (see Evans and Jovanovic 1989). ${ }^{12}$ This leads to the expectation of a positive sign of the estimated coefficient of the age variable. On the other hand one has to acknowledge that starting a new business often leads to high sunk costs - think of all the effort to set up a business plan, doing market research, dealing with legal and administrative problems, etc. The shorter the expected life span of the new business, the shorter is the period over which these

\footnotetext{
${ }^{10}$ See Le (1999) and Parker (2004, ch. 3) for a comprehensive "wish-list" of information that should ideally be included in an empirical model for the decision to become self-employed or not.

11 This definition of a nascent entrepreneur is identical to the definition used in the multicountry GEM project mentioned in footnote 1; see Reynolds et al. 2000, p.9.

${ }^{12}$ Remember that we were unable to collect more direct information on wealth in the survey.
} 
sunk costs can be earned back. To put it differently, setting up a new business with high sunk costs is more attractive at the age of 45 than at the age of 60 , ceteris paribus. This leads to the expectation of a negative sign of the estimated coefficient of the age variable. Given these two opposite influences of age on the propensity to become an entrepreneur it is an empirical question whether one dominates the other, or whether both net out (see Evans and Leighton 1989). To control for a non-linear influence of age on the decision to start a new firm age is included in squares, too.

- Fear of failure a reason not to start (a dummy variable taking the value one if the interviewee agreed that fear to fail would prevent him from founding a firm). Hypothesis: If the interviewee answered this question in the affirmative we consider this as an indicator of a high degree of risk aversion, and we expect a negative impact on the probability of becoming a nascent entrepreneur (see Kihlstrom and Laffont 1979).

- Role model (a dummy variable taking the value one if there is or was at least one selfemployed in the family of the interviewee). We expect a positive impact of contact with such a 'role model'. As Simon Parker (2004, p. 85) puts it, self-employed parents might offer their offspring informal induction in business methods, transfer business experience and provide access to capital and equipment, business networks, consultancy and reputation. Furthermore, children of self-employed parents can be expected to have more pro-business attitudes on average.

While the role of age, risk aversion, and family background are widely discussed in the entrepreneurship literature and, therefore, can be dealt with in a rather cursory way here, this does not hold for the rest of the variables included in our empirical model, dealing with the jack-of-all-trades theory, and with the age and size of the firm a person is or has been working in.

In a recent paper Lazear (2002) proposed the jack-of-all-trades view of entrepreneurship. Based on a coherent model of the choice between self-employment and paid employment he shows that having a background in a large number of different roles increases the probability of becoming an entrepreneur. The intuition behind this proposition is that entrepreneurs must have sufficient knowledge in a variety of areas to put together the many 
ingredients needed for survival and success in a business, while for paid employees it suffices and pays to be a specialist in the field demanded by the job taken. The variety of professional experience of an interviewee that is at the heart of Lazear's theory of entrepreneurship is measured by two variables:

- The survey includes a tailor-made question asking in how many different professional fields the interviewee has been active in the past, explaining that this does not mean the number of employers she/he worked for. The answer is included in the empirical investigation as the number of fields of experience.

- The survey collects information about professional degrees completed after school, i.e. whether or not the interviewee successfully passed apprenticeship, managed to qualify formally as a master craftsperson, or received a degree from a polytech or university. The number of professional degrees (ranging from zero to three) is included as a variable in the empirical investigation. ${ }^{13}$

- As regards the characteristics of the firm a person is working in we consider both firm size and firm age. Hypothesis: A stylized fact emerging from a vast number of empirical studies on the inter-regional differences in new firm formation is that the start-up rate in a region tends to be positively related to the share of employees working in small firms, or the proportion of small firms among all firms in the region (see, e.g., Mason 1991, Audretsch and Fritsch 1994, Gerlach and Wagner 1994, Reynolds, Storey and Westhead 1994, Armington and Acs 2002). A similar point has been made in studies dealing with inter-industry differences in new firm formation (see, e.g., Beesley and Hamilton). A theoretical explanation for this empirical regularity argues that working in a small firm tends to provide employees with a much more relevant experience for starting a new business (e.g., contacts with customers, and with the owner of the firm who therefore provides a role model to follow) than working in a large firm (see, e.g., Johnson 1986 and Mason 1991).

If this arguments holds one should expect that people who are working in a small firm (or did so in the past) should have a higher propensity to step into self-employment than

\footnotetext{
${ }^{13}$ First evidence for the empirical validity of Lazear's theory using data for German female and male nascent entrepreneurs together is given in Wagner (2003a, 2003b).
} 
others who work(ed) for a large enterprise. A similar argument can be made for those who work(ed) in young firms compared to those in old firms: Through a close contact to a successful entrepreneur people in a young firm have the opportunity to gather information about the transition from paid employment to self employment with all its problems, and about possible solutions (see, e.g., Sorensen and Audia 2000). The "employer-as-a-rolemodel" argument put forward in the context of the small firm should be even more relevant here, because not all small firms are young (and, therefore, not all owners of small firms are role models for potential starters of new firms today), but most of the young firms are small. And we expect it to be most relevant in the case of work experience gathered in a young and small firms.

Evidence on the ceteris paribus role played by the size of the firm a person is or has been working in for the decision to start a new business is scarce. Blanchflower and Meyer (1994) provide an econometric study looking at the ceteris paribus impact of firm size on the transition into self-employment; for a sample of Australians, they find that the probability to step into self-employment decreases with firm size. Similar evidence is reported by Boden (1996) for the US; he finds a greater propensity of small business employees to switch to selfemployment. Using large random samples of economically active adults from Germany Strohmeyer and Leicht (2000) show that those who completed their vocational training in a small firm are more likely to become self-employed than those trained in large firms.

The role played by firm age for the individual decision to start a new business has been investigated econometrically in Wagner (2004) using the same data set as in this study. Accordingly, people from young and small firms have a higher probability to become nascent entrepreneurs, ceteris paribus.

Firm age is measured in years. Given that we do not expect that it matters whether a firm is, say, 25 or 145 years old, we define a young firm to be at most 10 years old. Firm size is measured by the number of employees working in a firm. Firms with less than or equal to 
20 employees are considered to be small firms. Furthermore, we will look at the group of firms that are both young and small according to the definition used here. ${ }^{14}$

\section{Descriptive information}

Descriptive statistics by gender for the variables used in this study are reported in table I. In the sample considered here the percentage of nascent entrepreneurs is about twice as high for men (4.7 percent) than for women ( 2.4 percent) - this gender gap has exactly the same order of magnitude as the gender gap found for the self-employed, and for those wishing to become self-employed, cited for Germany in the first paragraph of this paper. Furthermore, the differences in mean values between men and women for all characteristics and attitudes are statistically significant at an error level of ten percent or lower. However, these differences are negligible from an economic point of view for age, number of fields of experience, number of professional degrees, and presence or not of a role model in the family. Statistically significant and large (in an economic sense) differences between men an women are found for risk aversion - the proportion of those who consider fear of failure to be a reason not to start an own business is 12 percentage points higher for women than for men - and for work in

\footnotetext{
${ }^{14}$ A more detailed discussion of how to measure firm age and firm size with the REM data, and comparable results for empirical models using continous and categorical measures, can be found in Wagner (2004). In the survey some interviewees reported an incredibly high number of employees in their firm (up to 700.000!). From the raw data we get an average firm size of 6.774 employees. These figures are nonsense. According to the Federal Statistical Office in 1999 there were only 749 firms in the industrial sector that had 1.000 or more employees. These very large firms employed 2.6 million persons - or 3.471 on average. In 2000 , the average number of employees in all industrial establishments was about 130. Firms from private services and from building and construction tend to be much smaller on average (see Statistisches Bundesamt 2002, p. 289ff.). I decided to drop all (195) cases with a firm size that exceeds 17.000 employees - about five times the average number of employees among the group of the largest firms in the manufacturing sector. A comparison of the descriptive statistics from the whole sample and the reduced sample reveals no differences apart from the average firm size; the table is available on request.
} 
small, young, and small, young firms - the shares of women who are working in these "hothouses" for nascent entrepreneurs are much higher than the respective shares of men.

\section{[Table I near here]}

Next, we will compare nascent entrepreneurs and paid employees, starting with men. According to the results reported in table II, on average nascents are younger, have more fields of experience, do less often consider fear of failure a reason not to start an own business, have more often a role model in their families, and are more often working in small, young, and small, young firms. All these differences are statistically significant at an error level of five percent or lower, are large from an economic point of view, and are in line with our priors stated above. The only exception from this rule is the number of professional degrees - on average, there is no difference between nascent entrepreneurs and paid employees here.

[Table II near here]

By and large, a similar picture can be found in table III where female nascent entrepreneurs are compared with paid employees. Again, on average nascents have more fields of experience, do less often consider fear of failure a reason not to start an own business, have more often a role model in their families, and are more often working in small, young, and small, young firms. With the exception of the number of fields of experience, these differences are statistically significant at an error level of ten percent or lower, large from an economic point of view, and in line with the theoretical priors. As is the case for men, the number of professional degrees does not differ between female nascent entrepreneurs and paid employees. Contrary to the evidence reported for males, female nascents tend to be about two years older than paid employees on average; this difference, however, is not statistically significant at an error level of ten percent. 
[Table III near here]

As a final step in our descriptive analysis, male and female nascent entrepreneurs are compared. According to the results reported in table IV, on average male nascents are much younger than females (and this difference is statistically highly significant), and they have about one more field of experience. Furthermore, the share of female nascents working in small, young, and young, small firms is higher compared to males, although only the difference for "small firms" is statistically significant at a common level.

[Table IV near here]

\section{Results of the econometric study}

\subsection{A parametric approach: Rare events logit models}

The descriptive evidence given in section 4 above has documented significant differences in characteristics and attitudes between men and women, between nascent entrepreneurs and paid employees, and between male and female nascent entrepreneurs. What is the ceteris paribus impact of these characteristics and attitudes on the decision to become a nascent entrepreneur? Which part of the gender gap in entrepreneurship can be explained by these endowments? As a first step towards an answer to these questions, the ceteris paribus role played by gender in determining the probability of becoming a nascent entrepreneur when characteristics and attitudes of the interviewees are controlled for is investigated in an econometric model with a dummy endogenous variable taking the value one if a person is a nascent entrepreneur, zero otherwise. ${ }^{15}$

15 This type of empirical model has been labeled the "reduced-form self-employment equation" by Le (1999). Note that in his survey Le mentions that studies using this approach primarily focus on males aged 16 - 64 years; in his table 4 he lists only three papers that report results for specifications with a gender dummy variable, and no study that looks at gender differences in depth. Parker (2004) does not include gender as one of the determinants 
Starting a new business is a rare event; only 132 (or 3.6 percent) of all persons included in the sample are nascent entrepreneurs; 91 of them are males, 41 are females. Application of standard textbook probit or logit methods to estimate the empirical models is not appropriate here. Gary King and Langche Zeng (2001a, 2001b) recently developed a version of the logit model to compute unbiased estimates in a situation like this. This method - labeled Rare Events Logistic Regression, or RELOGIT - is applied here. RELOGIT estimates the same logit model as the standard logit procedure, but uses an estimator that gives lower mean square error in the presence of rare events data for coefficients, probabilities, and other quantities of interest. Furthermore, to take the survey design into account and to allow that the observations might be dependent within a planning region, the variances of the estimated coefficients were estimated with the region as a cluster. ${ }^{16}$ Note that spatial autocorrelation is not an issue in our study because the planning regions are scattered all over Germany.

In the econometric investigation three different variants of the empirical model were estimated. All variants include an identical set of variables (for age, risk aversion, presence of a role model, numbers of fields of experience and professional degrees, and dummy variables indicating whether a person works or worked in a small firm, a young, and in a young, small firm), but they differ in the way gender enters the model. Model A and model B is estimated for males and females only, respectively; model $\mathrm{C}$ includes a dummy variables which takes the value one if the person is male, and zero otherwise, plus a full set of interaction terms of all variables and the male dummy variable. Results are reported in table V.

[Table V near here]

To start with the determinants of becoming a male nascent entrepreneur, from the estimated coefficients of model A and their prob-values we see that the number of fields of experience, risk aversion, and working in a young and small firm matter (and in a way that is

in entrepreneurship in his summary table 3.3 which gives a synopsis of the findings of dozens of empirical investigations.

${ }^{16}$ All computations were done with Stata 8.2 (see StataCorp 2003) using the RELOGIT adofile available from Gary King's homepage at Harvard <http://gking.harvard.edu>. 
in accordance with our theoretical priors) - all other variables included in the empirical model are statistically insignificant at any conventional level. Model B paints a different picture for female nascents: Again, fear of failure matters, but other than for males neither the number of fields of experience, nor work experience in a young and small firm, has any statistically significant effect. Contrary to male nascents, age matters for females - the estimated coefficients tend to show that the propensity to step into self-employment increases up to the age of 40 years, and decreases afterwards. Like in the case of males, all the other variables included are statistically insignificant at any conventional level. To summarize, we find that, on the one hand, results from bivariate comparisons of mean values for nascent entrepreneurs and paid employees (reported in tables II and III) and ceteris paribus results from the econometric models differ, and that, on the other hand, results from the empirical models estimated for men and women differ, too.

To shed more light on the differences between the coefficient estimates from the empirical models for male and female nascent entrepreneurs, these models were augmented with a dummy for males, and a full set of interaction terms of this dummy variable with all variables included in models $\mathrm{A}$ and $\mathrm{B}$. The augmentend model was estimated for both men and women; results for model $\mathrm{C}$ are reported in the last column of table $\mathrm{V}$. By construction, the coefficient estimates (and the prob-values) for the variables included both in model A and model B are identical to those from model B (i.e., the estimation results for females). The dummy variable for males is positive and statistically significant, pointing to an upward shift in the level of the probability to become a nascent entrepreneur when men are compared to women, irrespective of the values of the regression coefficients for the variables included in the model. By construction, the coefficient estimates for the interaction terms are the differences between the coefficient estimates for males and females from model A and B. A joint test rejects the null hypothesis that all these coefficients of the interaction terms are zero at any level of significance. ${ }^{17} \mathrm{~A}$ closer look reveals, however, that only the estimated

${ }^{17}$ The empirical chi2(9) - value is 169.90 with a prob-value of 0.0000 . If the sex dummy is included in the set of coefficients looked at in the joint test, the respective chi2(10) - value is 6756.33 with a prob-value of 0.0000 . These results indicate that it is not appropriate to pool data for male and female nascents and add a gender dummy to an empirical model without 
coefficient for the interaction term of the dummy variable for males and the variable indicating that fear of failure is considered as a reason not to start an own business is statistically significantly different from zero at a conventional level. This coefficient estimate is positive, pointing out that fear of failure has a smaller negative influence on the propensity to step into self-employment for men than for women. For all the other interaction terms the null hypothesis that the estimated coefficients from model A (for men) and model B (for women) do not differ can not be rejected at a conventional error level.

Discussion of results hitherto was limited to the statistical significance of the estimated coefficients and the direction of influence conducted by the variables. Information on the extent of this influence, or on the economic importance, however, is even more important. Evidently, a variable that has no statistically significant impact can be ignored from an economic point of view, but the opposite is not true: A variable that is highly significant statistically might not matter at all economically - if the estimated probability for becoming a nascent entrepreneur diminishes by 0.00001 percent when a person considers fear of failure as a reason not to start a business, we can ignore the "fear of failure" - variable in any discussion on nascent entrepreneurs irrespective of any high level of statistically significance indicated by the prob-value.

Unfortunately, the estimated coefficients from a rare events logit model (or for any other non-linear model) can not easily be used for statements about the size of the ceteris paribus effect of a change of the value of an exogenous variable (e.g., to consider fear of failure as a reason not to start a business, or not to do so) on the value of the endogenous variable (e.g., the probability of becoming a nascent entrepreneur), because the size of this effects depends on both the value of the exogenous variable under consideration and on the values of all other variables in the model (see Long and Freese, 2001, 87ff.).

A way to ease interpretation of the estimation results is to compute the estimated values of the endogenous variable (here: the probability of becoming a nascent entrepreneur) for a

checking carefully whether single variables have different effects for men and women. This point has not been taken care of in numerous empirical studies on the determinants of entrepreneurship, including earlier studies by the author and others with German data mentioned in footnote 3 . 
person with certain characteristics and attitudes, and to show how a change in the value of one exogenous variable at a time changes the estimated probability.

For expository purposes, we start by looking at an "average person" with values for all the exogenous variables exactly equal to the sample averages for males listed in table I (ignoring the obvious fact that dummy variables can only take the value zero or one for any real person). If this person is a man, according to the results reported for model A in table 5 for this hypothetical person the estimated probability to be a nascent entrepreneur is 3.5 percent. ${ }^{18}$ If this person is a women instead, the probability (computed by using model B) goes down to 1.6 percent - less than half the value computed for our average person if he is treated as a man. A similar pattern is observed for a hypothetical average person with values of the exogenous variables that are set at the sample average for woman: using model B the estimated probability is 1.5 percent, based on model A we get 3.3 percent. Gender matters.

To illustrate the importance of "fear of failure" let us now look at a person who is 39.46 years old, has 3.51 fields of experience and 1.09 professional degrees (these are the average values for males in the sample), has a role model in his family, and works in a small and young firm. If this person does not consider fear of failure a reason not to start an own business, and if it is a man, according to model A the probability that he is a nascent entrepreneur is 17.8 percent; if the same person is a women, according to model B this probability is 12.8 percent. Now let us assume that the person does consider fear of failure a reason not to start an own business. If he is a man, the probability of being a nascent entrepreneur drops from 17.8 percent to 9.0 percent, i.e. by a factor 2 . If she is a women, it drops from 12.0 percent to 2.4 percent, i.e. by a factor 5 . Gender matters a lot as regards the influence of fear or failure on the propensity to become a nascent entrepreneur - statistically and economically!

According to the results from the descriptive comparisons between males and females discussed in section 4 both groups differ on average with respect to characteristics (like the share of employees from young and small firms) and attitudes (like the share of those who

\footnotetext{
18 All simulations were done in Stata 8.2 using the SETX and RELOGITQ programs that come with RELOGIT; see footnote 16.
} 
consider the fear of failure to be a reason not to start an own business), or for short, in their average endowments. The results from the rare events logit estimates of the empirical models reported above indicate that all but one endowments are not related differently to the propensity to step into self-employment for men and women - the differences in the estimated coefficients between model A and model B are not statistically different from zero, the one exception being fear of failure (and the constant term). How large is the part of the gender gap in the propensity to become a nascent entrepreneur that can be explained by differences in endowments, and how much of it is due to differences in behavior as reflected in different coefficients (including the different constant terms)?

One approach that might be considered to investigate this topic is the application of the so-called Oaxaca-Blinder decomposition introduced into the economics literature some thirty years ago by Ronald Oaxaca and Alan Blinder. This technique splits up the gender wage differential into a portion that arises because men and women, on average, have different skills, and a portion not explained by these skill differentials that is often labeled labor market discrimination (see Blinder 1973; Oaxaca 1973; Oaxaca and Ransom 1994). It is discussed in introductory textbooks on labor economics (e.g., Borjas 2000, p. 362ff.), and it has been used in the literature on self-employment to investigate earnings differentials between selfemployed men and women (see Parker 2004, p. 126ff.). One might be tempted to apply this type of decomposition to the problem under investigation here to split up the gender differential in self-employment into a portion that arises because men and women, on average, have different characteristics and attitudes, or endowments, as documented in table I, and a portion attributable to different coefficients, or rates of return with respect to the propensity to become self-employed, as reported in table V. This research strategy, however, is not technically feasable. While the standard Oaxaca-Blinder decomposition is based on empirical models (for males and females, or for two groups that differ in any other aspect under study) that were estimated by ordinary least squares, the empirical models for becoming a male or 
female nascent entrepreneur are estimated by rare events logit, and the decomposition technique can not be applied. ${ }^{19}$

\subsection{A non-parametric approach: Mahalanobis-distance matching}

An alternative path towards an answer to the question how much of the gender gap in the propensity to become a nascent entrepreneur is due to differences in endowments, and how much is due to differences in behavior, starts with asking a different but closely related hypothetical question: Would a man with a given set of characteristics and attitudes be a nascent entrepreneur or not if he were a woman? Obviously, there is no direct way to find out for any single person, because we are unable to record the behavior of a man acting like a woman, and vice versa. If case number 478 in our sample is a female paid employee, we will never know whether she would be a male nascent entrepreneur or not. The counterfactual situation is unobservable, and, therefore, the individual causal effect of being a man or a

19 Details aside, the Oaxaca-Blinder decomposition uses the well-known fact that the regression hyperplane estimated by OLS passes through the point of means of the data (this is derived from the first normal equation; see Greene 2000, p. 230). If the empirical models for becoming a male or female nascent entrepreneur were estimated by OLS, therefore, this technique could be used. However, the endogeneous variable in these models is a binary variable, and we know from introductory textbooks that application of OLS (in the form of a linear probability model) is not appropriate (e.g., Studenmund 2001, p. 436ff.). Extensions of the Oaxaca-Blinder decomposition technique to models for binary choice using a logit approach are available (Nielsen 1998; Fairlie 1999, 2003; Yun 2004). Here a useful property of the logit regression that includes a constant term is used - the average of the predicted probabilities must equal the proportion of ones (in our case, the proportion of nascent entrepreneurs) in the sample. However, Langche Zeng, the co-author of the King/Zeng papers on rare events logit, pointed out (in private correspondence on March 24, 2004) that this property, which is directly implied by the logit normal equation, does not need to hold in rare events logit, since the normal equation effectively changes from that of the standard logit. Instead of switching to an inappropriate technique (like a linear probability model, or the standard logit) and applying the Oaxaca-Blinder decomposition, I decided to stay with rare events logit and to refrain from using the decomposition technique. 
women (ceteris paribus, i.e. with a fixed set of endowments) on the propensity to be a nascent entrepreneur must remain unknown.

A way out is to take the women in the sample and to construct a control group of men in such a way that every woman is matched to a man that is as similar as possible (ideally, identical) with regard to all the relevant characteristics and attitudes (besides gender). By construction, the mean values for the characteristics and attitudes between the women and the men from this control group do not differ significantly if this matching has been successful. From the survey we know for each women and each man whether (s)he is a nascent entrepreneur or not. The difference in the percentage of nascent entrepreneurs between the group of females in the sample and the matched control group of men, therefore, can be seen as an estimate of the causal effect of gender on the propensity to become a nascent entrepreneur. ${ }^{20}$ If, for example, in the complete sample we have 6 percent of nascents among all males, and 3 percent among all females, the raw differential is 3 percentage points (or 100 percent). If the portion of nascents among the group of matched males is 5 percent, the

${ }^{20}$ In a sense this resembles a situation familiar from the evaluation of active labor market programs (or any other form of treatment of units): If participants, or treated units, are not selected randomly from a population but are selected or self-select according to certain criteria, the effect of a treatment cannot be evaluated by comparing the average performance of the treated and the non-treated. However, given that each unit (plant, or person, etc.) either participated or not, we have no information about its performance in the counterfactual situation. A way out here is to construct a control group in such a way that every treated unit is matched to an untreated unit that has been as similar as possible (ideally, identical) at the time before the treatment. Differences between the two groups (the treated, and the matched non-treated) after the treatment can then be attributed to the treatment (for a comprehensive discussion, see Heckman, LaLonde and Smith 1999). Obviously, gender can not literally be seen as a treatment because not all people have been men sometimes in the past, and then half of them were treated to become women. However, the idea behind the procedure can be used to net out the effects of differences in endowments. The approach to consider the gender variable as a treatment and use matching to select sub-samples of males and females such that there are no differences in observable characteristics between the matched groups has been used before by Nopo (2004) to decompose the gender wage gap; to the best of my knowledge, it has not been applied to look at gender differences in the propensity to become a nascent entrepreneur before. 
difference due to gender (holding endowments constant) is 2 percentage points (or 66.6 percent of the raw differential), and the rest of 1 percentage point (or 33.3 percent of the raw differential) is due to differences in endowments.

To implement this approach, each woman in the sample is matched to a man whose vector of characteristics and attitudes has the minimum Mahalanobis distance from the vector of the woman. ${ }^{21}$ Matching was successful; a comparison of mean values for women and matched man reported in table VI shows no statistically significant differences at an error level of 5 percent. $^{22}$

[Table VI near here]

The use of Mahalanobis-distance matching of man and woman that are as similar as possible in all characteristics and attitudes but the "small difference", and looking at the difference in the propensity to become self-employed between these groups of "twins", is a non-parametric approach to compute the average effect of being female on the propensity to become a nascent entrepreneur (or, in the language of the program evaluation literature, to compute the average effect of the treatment on the treated). An advantage of this nonparametric approach is that, contrary to the estimation of the logit models, we do not have to assume a functional form for the self-employment equation.

In the matched sample, the proportion of females which are nascent entrepreneurs is by construction unchanged, i.e. 2.40 percent, while the proportion of male nascents is 4.80

\footnotetext{
${ }^{21}$ The Mahalanobis distance (MD) is defined as follows: Let XM (XF) be a column vector of variables for males and females, respectively, and $G$ the inverse of the covariance matrix; then $\mathrm{MD}=(\mathrm{XM}-\mathrm{XS})^{\prime} \mathrm{G}(\mathrm{XM}-\mathrm{XS})$. Matching was performed in Stata 8.2 using the PSMATCH2 command (Leuven and Sianesi 2003).

${ }^{22}$ Testing for differences after matching was done with the Stata ado-file PSTEST1 provided by Edwin Leuven on March 11, 2004. Note that some men were matched with more than one woman due to matching with replacement; a total of 873 men was used to match 1708 women: 434 men were used once, 236 were used twice, and 101, 60, 24, 8, 4 and 3 were used 3, 4, 5, 6,7 and 8 times; in three cases, one man has been used 9, 12 and 18 times, respectively.
} 
percent - and that is 0.11 percentage points higher than the respective proportion in the unmatched sample (which is 4.69 percent). Taken at face value, from this it follows that if women had the same characteristics as men on average the gender gap in nascent entrepreneurship would even be higher than it is now when these endowments differ. To put it differently, it is only gender specific behaviour that matters, not endowment differences by gender.

When interpreting the computed value for the effect of the treatment on the treated one must, however, keep in mind that this value is based on a sample of all men and women only it is, therefore, an estimate of the treatment effect with a sampling distribution. While we have no formula for the sampling distribution of the effect we can estimate the standard errors for

the computed effect by bootstrapping, and construct a confidence interval for it. ${ }^{23}$ Using 1000 replications the bias corrected 95 percent confidence interval for the computed treatment effect of -0.0234 (or -2.34 percent) is [-0.0428, -0.0034$]$, or between -4.28 percent and -0.034 percent. Based on this result we can reject the null hypothesis that being female has no negative effect on the propensity of becoming a nascent entrepreneur at an error level of 5 percent; the effect itself, however, is rather imprecisely estimated. It seems that the nonparametric matching approach asks too much from the sample at hand which includes only 41 female nascent entrepreneurs, and the 37 matched male nascents.

\section{Conclusions}

This paper starts from the stylized fact that in western industrialized countries men are on average more than twice as active in entrepreneurship as women, and from the statement that

${ }^{23}$ In a nutshell, bootstrapping consists of drawing, with replacement, $\mathrm{N}$ observations from our $\mathrm{N}$ observations data set. In this new sample, some of the original observations appear once, some more than once, and some are not in it. The average effect of the treatment on the treated is computed using this new sample. This procedure is repeated for a number of times (e.g., 1000 times), leading to a new random sample, and a new estimate of the effect, in each replication. From the estimates for the effect (in our example, 1000) one calculates the standard deviation using the standard formula. Bootstrapping was performed with Stata 8.2, see StataCorp (2003) for details and references to the statistical literature. 
little is known about precisely why this is the case, with Germany being a case point. Using data from a recent representative survey of the adult German population an empirical model for the decision to become self-employed is estimated to test for differences between women and men in the ceteris paribus impact of several characteristics and attitudes, taking the rare events nature of becoming an entrepreneur into account. Furthermore, a non-parametric approach using Mahalanobis-distance matching of man and woman who are as similar as possible is used to investigate the difference in the propensity to become self-employed by gender.

The bottom line of this empirical exercise in looking at the differences between female and male nascent entrepreneurs is that considering fear of failure to be a reason not to start an own business matters a lot. The estimated coefficient for the interaction term of the dummy variable for males and the variable indicating that fear of failure is considered as a reason not to start an own business is statistically significantly different from zero at a conventional level and positive, pointing out that fear of failure has a smaller negative influence on the propensity to step into self-employment for men than for women. Given that only 44 percent of all men, but 56 percent of all women, in the sample consider fear of failure a reason not to become self-employed, this gender specific difference in risk aversion is important. This finding fits well with results on gender specific differences in risk aversion from other areas. Summarizing a large literature, Eckel and Grossman (2003) argue that "(d)ifferences between women and man in attitudes toward risk are well documented across a variety of situations and environments. Studies have found women more likely to perceive a situation as risky. Women also exhibit greater risk aversion in their choice behavior and lower valuations of risky prospects. They are found to have less risky asset portfolios than men, and report a lower propensity to assume financial risk than men." In the context of entrepreneurship Carter (2002) states that female founders are more risk averse and less likely to expect debt financing to capitalize their businesses. It is an open question, however, whether these gender differences in behaviour towards risk is deeply routed in the past of the human species, or whether it is due to different socialization men and women are subjected to due to their observed sex, as is argued by social feminist theories (see Fischer, Reuber and Dyke 1993). 
Maybe, economists should leave the search for an answer to this question to colleagues from other sciences, including sociology and biology, noting that our comparative advantage lies in dealing with different aspects of gender differences in entrepreneurship.

Furthermore, the part of the gender differential in nascent entrepreneurship explained by different behaviour towards risk, and the reason(s) for the remaining part, are important topics for future research that have to be resolved before sound policy measures aimed at fostering entrepreneurial activities by women can be framed.

\section{References}

Alsos, Gry Agnete and Elisabet Ljunggren (1998), Does the Business Start-Up Process Differ by Gender? A Longitudinal Study of Nascent Entrepreneurs. Frontiers of Entrepreneurial Research . Babson College, Wellesley, MA.

Armington, Catherine and Zoltan J. Acs (2002), The Determinants of Regional Variation in New Firm Formation. Regional Studies 36, 33-45.

Audretsch, David B. (2002), Entrepreneurship: A Survey of the Literature. Prepared for the European Commission, Enterprise Directorate General. Institute for Development Strategies, Indiana University, mimeo, July.

Audretsch, David B. and Michael Fritsch (1994), The Geography of Firm Births in Germany. Regional Studies 28, 359-365.

Beesley, M. E. and R. T. Hamilton (1984), Small Firms Seedbed Role and the Concept of Turbulence. Journal of Industrial Economics XXXIII, 217-231.

Bergmann, Heiko (2004), Gründungsaktivitäten im regionalen Kontext. Eine Untersuchung von Gründern, Gründungseinstellungen und Rahmenbedingungen in zehn deutschen Regionen auf der Basis von Mikrodaten. (Kölner Forschungen zur Wirtschafts- und Sozialgeographie, 57) Köln: Universität zu Köln (in press).

Bergmann, Heiko, Andrea Japsen and Christine Tamasy (2002), Regionaler Entrepreneurship Monitor (REM) - Gründungsaktivitäten und Rahmenbedingungen in zehn deutschen Regionen. Universität zu Köln and Universität Lüneburg. 
Blanchflower, David G. (2004), Self-employment: More may not be better. National Bureau of Economic Research (NBER) Working Paper 10286, February.

Blanchflower, David G. and Bruce D. Meyer (1994), A Longitudinal Analysis of the Young Self-Employed in Australia and the United States. Small Business Economics 6, 1-19.

Blinder, Alan S. (1973), Wage Discrimination: Reduced Form and Structural Variables, Journal of Human Resources 8, 436-455.

Boden, Richard J. (1996), Gender and Self-Employment Selection: An Empirical Assessment, Journal of Socio-Economics 25, 671-682.

Borjas, George J. (2000), Labor Economics. Second Edition. Boston etc.: McGraw-Hill.

Brown, Charles, James Hamilton, and James Medoff (1990), Employers Large and Small. Cambridge, Mass.: Harvard University Press.

Carr, Deborah (1996), Two paths to self-employment? Women's and men's self-employment in the United States, 1980, Work and Occupations 23, 26-53.

Carter, Nancy (1997), Entrepreneurial Processes and Outcomes: The Influence of Gender, in: Paul D. Reynolds and Sammis B. White, The Entrepreneurial Process. Economic Growth, Men, Women, and Minorities. Westport, Connecticut, and London: Quorum Books.

Carter, Nancy (2002), The Role of Risk Orientation on financing Expectations in New Venture Creation: Does Sex Matter? Frontiers of Entrepreneurial Research. Babson College, Wellesley, MA.

Carter, Nancy and Lars Kolvereid (1998), Woman starting new businesses: The experience in Norway and the United States, in: OECD, Women Entrepreneurs in Small and Medium Enterprises. Paris: OECD Publications.

Carter, Sara (2001), Women's Business Ownership: A Review of the Academic, Popular and Internet Literature. Report to the Small Business Service. Department of Marketing, University of Strathclyde, mimeo, August.

Delmar, Frederic and Per Davidsson (2000), Where do they come from? Prevalence and characteristics of nascent entrepreneurs. Entrepreneurship \& Regional Development 12, $1-23$. 
Eckel, Catherine C. and Philip J. Grossman (2003), Forecasting Risk Attitudes: An Experimental Study of Actual and Forecast Risk Attitudes of Woman and Men. Mimeo, Virginia Tech and St. Cloud State University, October.

Engel, Dirk and Friederike Welter (2004), Dreamers and Doers - Who succeeds in the Process of Venture Creation? Draft, RWI Essen, January.

Evans, David S. and Boyan Jovanovic (1989), An Estimated Model of Entrepreneurial Choice under Liquidity Constraints. Journal of Political Economy 97, 808-827.

Evans, David S. and Linda S. Leighton (1989), Some Empirical Aspects of Entrepreneurship. American Economic Review 79, 519-535.

Fairlie, Robert W. (1999), The Absence of the African-American Owned Business: An Analysis of the Dynamics of Self-Employment, Journal of Labor Economics 17, 80108.

Fairlie, Robert W. (2003), An Extension of the Blinder-Oaxaca Decomposition Technique to Logit and Probit Models. Economic Growth Center, Yale University, Discussion Paper No. 873 , November.

Fehrenbach, Silke and Maria Lauxen-Ulbrich (2002), A Gender View on Self-Employment in Germany. Institute for Small Business Research, University of Mannheim, mimeo.

Fischer, Eileen M., A. Rebecca Reuber and Lorraine S. Dyke (1993), A Theoretical Overview and Extension of Research on Sex, Gender, and Entrepreneurship. Journal of Business Venturing 8, 151-168.

Gerlach, Knut and Joachim Wagner (1994), Regional differences in small firm entry in manufacturing industries: Lower Saxony, 1979 - 1991. Entrepreneurship \& Regional Development 6, 63-80.

Georgellis, Yannis and Howard J. Wall (2000), Gender Differences in Self-Employment: Panel Evidence from Germany. Federal Reserve Bank of St. Louis Working Paper 99008B, November.

Greene, William H. (2000), Econometric Analysis. Fourth Edition. Upper Saddle River, NJ: Prentice Hall International. 
Heckman, James J., Robert J. LaLonde, and Jeffrey A. Smith (1999), The economics and econometrics of active labor market programs, in: Orley C. Ashenfelter and David Card, eds., Handbook of Labor Economics Volume 3A, 1865-2097. Amsterdam: NorthHolland.

Hübler, Olaf (1991), Was unterscheidet Freiberufler, Gewerbetreibende und abhängig Beschäftigte? Eine ökonometrische Untersuchung über Gruppenheterogenität, Einkommensdeterminanten und Statuswechsler, Mitteilungen aus der Arbeitsmarkt- und Berufsforschung 24, 101-114.

Hübler, Olaf (1992), Selbständige in Ostdeutschland. Eine theoretische und mikroökonometrische Analyse, Vierteljahrshefte zur Wirtschaftsforschung, Heft 3/4, 107-129. Johnson, P. S. (1986), New Firms: An Economic Perspective. London: Allen and Unwin. Jungbauer-Gans, Monika (1993), Frauen als Unternehmerinnen. eine Untersuchung der Erfolgs- und Überlebenschancen neugegründeter Frauen- und Männerbetriebe. Frankfurt am Main etc.: Peter Lang.

KfW Bankengruppe, Ed. (2004), Chefinnensache. Frauen in der unternehmerischen Praxis. Heidelberg: Physica.

Kihlstrom, Richard E. and Jean-Jacques Laffont (1979), A General Equilibrium Entrepreneurial Theory of Firm Formation Based on Risk Aversion. Journal of Political Economy 87, 719-748.

King, Gary and Langche Zeng (2001a), Logistic Regression in Rare Events Data, Political Analysis 9 (2), 137-163.

King, Gary and Langche Zeng (2001b), Explaining Rare Events in International Relations, International Organization 55 (3), 693-715.

Lauxen-Ulbrich, Maria and René Leicht (2003), First Statistical Overview - National Report on Women (Start-up) Entrepreneurs and Female Self-employed in Germany. Small Business Research Institute, University of Mannheim, mimeo.

Lazear, Edward P. (2002), Entrepreneurship. National Bureau of Economic Research Working Paper 9109, August. 
Le, Anh T. (1999), Empirical Studies of Self-Employment, Journal of Economic Surveys 13, $4,381-416$.

Lechner, Michael and Friedhelm Pfeiffer (1993), Planning for Self-Employment at the Beginning of a Market Economy: Evidence from Individual Data of East German Workers, Small Business Economics 5, 111-128.

Leicht, René and Friederike Welter, Ed. (2004), Gründerinnen und selbständige Frauen. Potenziale, Strukturen und Entwicklungen in Deutschland. Karlsruhe: v. Loeper.

Leuven, Edwin and Barbara Sianesi (2003), PSMATCH2: Stata module to perform full Mahalanobis and propensity score matching, common support graphing, and covariate imbalance testing. http://ideas.repec.org/c/boc/bocode/s432001.html. Version 1.2.3.

Linan Alcalde, Francisco, Domingo Martin Martin and Rosario Gonzales Rodriguez (2002), Characteristics of nascent entrepreneurs in Germany, Paper presented at the $42^{\text {nd }}$ ERSA Conference, Dortmund, 27-31 August 2002, mimeo, Universidad de Sevilla.

Long, J. Scott and Jeremy Freese (2001), Regression Models for Categorical Dependent Variables using Stata. College Station, TX: Stata Press.

Mason, C. (1991), Spatial variations in enterprise: the geography of new firm formation. In R. Burrows (ed.) Deciphering the Enterprise Culture. Entrepreneurship, Petty Capitalism and the Restructuring of Britain. London and New York: Routledge.

McManus, Patricia A. (2001), Women's Participation in Self-Employment in Western Industrialized Nations, International Journal of Sociology 31, no. 2, 70-97.

Minitti, Maria and Pia Arenius (2003), Women in Entrepreneurship. Paper presented at "The Entrepreneurial Advantage of Nations: First Annual Global Entrepreneurship Symposium", United Nations Headquarters, April 29, 2003.

Moore, Carol S. and Richard E. Mueller (2002), The transition from paid to self-employment in Canada: the importance of push factors. Applied Economics 34, 791-801.

Nielsen, Helena Skyt (1998), Discrimination and detailed decomposition in a logit model, Economics Letters 61, 115-120.

Nopo, Hugo (2004), Matching as a Tool to Decompose Wage Gaps. Institute for the Study of Labor (IZA) Discussion Paper 981, January. 
Oaxaca, Ronald L. (1973), Male-Female Wage Differentials in Urban Labor Markets, International Economic Review 14, 693-709.

Oaxaca, Ronald L. and Michael R. Ransom (1994), On Discrimination and the Decomposition of Wage Differentials, Journal of Econometrics 61, 5-21.

OECD (2000), Employment Outlook. Paris: OECD.

Parker, Simon (2004), The Economics of Self-Employment and Entrepreneurship. Cambridge, UK, etc.: Cambridge University Press.

Reynolds, Paul D. (1997), Who starts new Firms? - Preliminary Explorations of Firms-inGestation. Small Business Economics 9, 449-462.

Reynolds, Paul D. et al. (2000), GEM Global Entrepreneurship Monitor. 2000 Executive Report. Kansas City: Kauffman Center for Entrepreneurial Leadership.

Reynolds, Paul D. et al. (2001), GEM Global Entrepreneurship Monitor. 2001 Executive Report. Kansas City: Kauffman Center for Entrepreneurial Leadership.

Reynods, Paul D., David Storey and Paul Westhead (1994), Cross-national Comparisons of the Variation in New Firm Formation Rates. Regional Studies 28, 443-356.

Rybczynski, Kate (2004), Gender Differences in the Incidence and Duration of SelfEmployment. Mimeo, Queen’s University, January.

Simpson, Wayne and Robert Sproule (1998), Econometric Analysis of Canadian SelfEmployment Using SLID. Income and Labour Dynamics Working Paper Series: Statistics Canada Product Number 75F002M, November.

Sorensen, Olav and Pino G. Audia (2000), The Social Structure of Entrepreneurial Activity: Geographic Concentration of Footwear Production in the United States, 1940 - 1989. American Journal of Sociology 106, 424-462.

StataCorp (2003), Stata Statistical Software: Release 8.0. College Station, TX: Stata Corporation.

Statistisches Bundesamt (2002), Datenreport 2002, Zahlen und Fakten über die Bundesrepublik Deutschland. Bonn: Bundeszentrale für politische Bildung. 
Sternberg, Rolf (2000), Entrepreneurship in Deutschland, Das Gründungsgeschehen im internationalen Vergleich, Länderbericht Deutschland 1999 zum Global Entrepreneurship Monitor. Berlin: edition sigma.

Sternberg, Rolf and Heiko Bergmann (2003), Global Entrepreneurship Monitor. Länderbericht Deutschland 2002. Universität zu Köln.

Sternberg, Rolf, Heiko Bergmann and Ingo Lückgen (2004), Global Entrepreneurship Monitor. Länderbericht Deutschland 2003. Universität zu Köln.

Strohmeyer, Robert and René Leicht (2000), Small Training Firms: A Breeding Ground for Self-Employment? International Journal of Sociology 30, no. 4, 59-89.

Studenmund, A. H. (2001), Using Econometrics, A Practical Guide. Fourth Edition. Boston etc.: Addison Wesley Longman.

Verheul, Ingrid, André van Stel and Roy Thurik (2004), Explaining female and male entrepreneurship across 29 countries, Centre for Advanced Small Business Economics (CASBEC), Erasmus University Rotterdam, mimeo, February.

Wagner, Joachim (2003a), Testing Lazear's jack-of-all-trades view of entrepreneurship with German micro data. Applied Economics Letters 10, 687-689.

Wagner, Joachim (2003b), Are Nascent Entrepreneurs Jacks-of-all-Trades? A Test of Lazear's Theory of Entrepreneurship with German data. Institute for the Study of Labor (IZA) Discussion Paper 911, September.

Wagner, Joachim (2003c), The impact of personal characteristics and the regional milieu on the transition from unemployment to self-employment: Empirical evidence for Germany. Jahrbücher für Nationalökonomie und Statistik 223, 204-222.

Wagner, Joachim (2003d), Taking a second chance - Entrepreneurial restarters in Germany. Applied Economics Quarterly 49, 255-272.

Wagner, Joachim (2004), Are young and small firms hothouses for nascent entrepreneurs? Evidence from German micro data. Institute for the Study of Labor (IZA) Discussion Paper 989, January. 
Wagner, Joachim and Rolf Sternberg (2004), Start-up activities, individual characteristics, and the regional milieu: Lessons for entrepreneurship support policies from German micro data. Annals of Regional Science 38 (in press).

Wagner, Joachim and Rolf Sternberg (2005), Personal and regional determinants of entrepreneurial activities: Empirical evidence from the Regional Entrepreneurship Monitor (REM) Germany. Jahrbuch für Regionalwissenschaft, Heft 1/2005 (forthcoming).

Welter, Friederike and Bernhard Lagemann (2003), Gründerinnen in Deutschland Potenziale und institutionelles Umfeld. Essen: Rheinisch-Westfälisches Institut für Wirtschaftsforschung.

Wießner, Frank (2001), Arbeitslose werden Unternehmer. Nürnberg: Institut für Arbeitsmarkt- und Berufsforschung der Bundesanstalt für Arbeit.

Yun, Myeong-Su (2004), Decomposing differences in the first moment, Economics Letters $82,275-280$. 
Table I

Descriptive statistics (Part I): All males and females in the sample

\begin{tabular}{|c|c|c|c|}
\hline & Male & Female & $\begin{array}{l}\text { Test of } \mathrm{H}_{0}: \\
\text { Difference }\end{array}$ \\
\hline & $\begin{array}{l}\text { Mean } \\
\text { Std. Dev. }\end{array}$ & $\begin{array}{l}\text { Mean } \\
\text { Std. Dev. }\end{array}$ & $\begin{array}{c}\text { in } \operatorname{means}=0 \\
(t-\text { value })\end{array}$ \\
\hline Nascent entrepreneur (Dummy; $1=$ yes) & 0.047 & 0.024 & $-3.78^{\star \star \star}$ \\
\hline & 0.21 & 0.15 & \\
\hline Age (years) & $\begin{array}{r}39.46 \\
0.24\end{array}$ & 40.10 & $1.87^{\star}$ \\
\hline Age (squared) & $\begin{array}{r}1667.94 \\
19.31\end{array}$ & $\begin{array}{r}1715.73 \\
20.23\end{array}$ & $1.71^{\star}$ \\
\hline Number of fields of experience & $\begin{array}{l}3.51 \\
2.66\end{array}$ & $\begin{array}{r}3.17 \\
2.42\end{array}$ & $-4.05^{\star \star \star}$ \\
\hline Number of professional degrees & $\begin{array}{l}1.00 \\
0.57\end{array}$ & $\begin{array}{l}2.42 \\
0.99 \\
0.51\end{array}$ & $-5.90^{\star \star \star}$ \\
\hline $\begin{array}{c}\text { Fear of failure a reason not to start } \\
\text { an own business (dummy; } 1=\text { yes) }\end{array}$ & $\begin{array}{l}0.44 \\
0.50\end{array}$ & $\begin{array}{l}0.56 \\
0.50\end{array}$ & $6.81^{\star \star \star}$ \\
\hline $\begin{array}{c}\text { Role model (dummy; } 1=\text { at least one } \\
\text { self-employed in the family }\end{array}$ & $\begin{array}{l}0.45 \\
0.50\end{array}$ & $\begin{array}{l}0.49 \\
0.50\end{array}$ & $2.67^{\star * \star}$ \\
\hline Small firm (dummy; $1-20$ employees) & $\begin{array}{l}0.24 \\
0.43\end{array}$ & $\begin{array}{l}0.42 \\
0.49\end{array}$ & $11.71^{\star \star \star}$ \\
\hline Young firm (dummmy; up to 10 years old) & $\begin{array}{l}0.19 \\
0.39\end{array}$ & $\begin{array}{l}0.24 \\
0.43\end{array}$ & $4.17^{\star \star \star}$ \\
\hline Young firm * small firm (interaction term) & $\begin{array}{l}0.09 \\
0.29\end{array}$ & $\begin{array}{l}0.16 \\
0.36\end{array}$ & $5.85^{\star \star \star}$ \\
\hline Number of cases & 1940 & 1708 & \\
\hline
\end{tabular}

${ }^{*},{ }^{*},{ }^{\star *}$ denote statistical significance at an error level of 10,5, and 1 percent. 
Table II

Descriptive statistics (Part II): Male nascent entrepreneurs vs. paid employees

\begin{tabular}{|c|c|c|c|}
\hline & $\begin{array}{c}\text { Nascent } \\
\text { Entrepreneur } \\
\text { Mean } \\
\text { Std. Dev. }\end{array}$ & $\begin{array}{l}\text { Paid } \\
\text { Employee } \\
\text { Mean } \\
\text { Std. Dev. }\end{array}$ & $\begin{array}{l}\text { Test of } \mathrm{H}_{0}: \\
\text { Difference } \\
\text { in means }=0 \\
(t-\text { value })\end{array}$ \\
\hline Age (years) & 35.26 & 39.66 & $4.45^{\star \star \star}$ \\
\hline Age (squared) & $\begin{array}{r}9.14 \\
1326 \cdot 12\end{array}$ & $\begin{array}{r}10.57 \\
1864.77\end{array}$ & $4.81^{\star \star \star}$ \\
\hline Number of fields of experience & $\begin{array}{r}686.11 \\
4.40 \\
3.64\end{array}$ & $\begin{array}{r}854.48 \\
3.47 \\
2.60\end{array}$ & $-2.40^{\star \star}$ \\
\hline Number of professional degrees & $\begin{array}{l}1.12 \\
0.53\end{array}$ & $\begin{array}{l}1.09 \\
0.57\end{array}$ & -0.55 \\
\hline $\begin{array}{r}\text { Fear of failure a reason not to start } \\
\text { an own business (dummy; } 1=\text { yes) }\end{array}$ & $\begin{array}{l}0.24 \\
0.43\end{array}$ & $\begin{array}{l}0.45 \\
0.50\end{array}$ & $4.54^{\star \star \star}$ \\
\hline $\begin{array}{c}\text { Role model (dummy; } 1=\text { at least one } \\
\text { self-employed in the family }\end{array}$ & $\begin{array}{l}0.59 \\
0.49\end{array}$ & $\begin{array}{l}0.44 \\
0.50\end{array}$ & $2.91_{\star \star \star \star}^{\star \star}$ \\
\hline Small firm (dummy; $1-20$ employees) & $\begin{array}{l}0.38 \\
0.49\end{array}$ & $\begin{array}{l}0.24 \\
0.42\end{array}$ & $-2.84^{\star \star \star}$ \\
\hline Young firm (dummmy; up to 10 years old) & $\begin{array}{l}0.37 \\
0.49\end{array}$ & $\begin{array}{l}0.18 \\
0.38\end{array}$ & $-3.82^{x \lambda}$ \\
\hline Young firm * small firm (interaction term) & $\begin{array}{l}0.27 \\
0.45\end{array}$ & $\begin{array}{l}0.08 \\
0.27\end{array}$ & $-4.05^{\star \star \star}$ \\
\hline Number of cases & 91 & 1940 & \\
\hline
\end{tabular}

$\star * \star, * \star \star$ denote statistical significance at an error level of 10,5, and 1 percent. 
Table III

Descriptive statistics (Part III): Female nascent entrepreneurs vs. paid employees

\begin{tabular}{|c|c|c|c|}
\hline & $\begin{array}{c}\text { Nascent } \\
\text { Entrepreneur } \\
\text { Mean } \\
\text { Std. Dev. }\end{array}$ & $\begin{array}{c}\text { Paid } \\
\text { Employee } \\
\text { Mean } \\
\text { Std. Dev. }\end{array}$ & $\begin{array}{c}\text { Test of } \mathrm{H}_{0}: \\
\text { Difference } \\
\text { in means = } 0 \\
\text { (t-value) }\end{array}$ \\
\hline Age (years) & $\begin{array}{r}41.85 \\
8.04\end{array}$ & $\begin{array}{l}40.06 \\
10.42\end{array}$ & -1.40 \\
\hline Age (squared) & $\begin{array}{r}1814.83 \\
675.19\end{array}$ & $\begin{array}{r}1713.29 \\
839.47\end{array}$ & -0.95 \\
\hline Number of fields of experience & $\begin{array}{l}3.51 \\
2.51\end{array}$ & $\begin{array}{l}3.17 \\
2.41\end{array}$ & -0.87 \\
\hline Number of professional degrees & $\begin{array}{l}1.05 \\
0.55\end{array}$ & $\begin{array}{l}0.98 \\
0.51\end{array}$ & -0.75 \\
\hline $\begin{array}{c}\text { Fear of failure a reason not to start } \\
\text { an own business (dummy; } 1=\text { yes) }\end{array}$ & $\begin{array}{l}0.17 \\
0.38\end{array}$ & $\begin{array}{l}0.57 \\
0.50\end{array}$ & $6.49^{\star \star \star}$ \\
\hline $\begin{array}{c}\text { Role model (dummy; } 1=\text { at least one } \\
\text { self-employed in the family }\end{array}$ & $\begin{array}{l}0.63 \\
0.49\end{array}$ & $\begin{array}{l}0.49 \\
0.50\end{array}$ & $-1 \cdot 91_{\star}^{\star}$ \\
\hline Small firm (dummy; $1-20$ employees) & $\begin{array}{l}0.56 \\
0.50\end{array}$ & $\begin{array}{l}0.42 \\
0.49\end{array}$ & $-1.77^{\star}$ \\
\hline Young firm (dummmy; up to 10 years old) & $\begin{array}{l}0.49 \\
0.51\end{array}$ & $\begin{array}{l}0.24 \\
0.42\end{array}$ & $-3.16^{\star \star \star}$ \\
\hline Young firm * small firm (interaction term) & $\begin{array}{l}0.39 \\
0.49\end{array}$ & $\begin{array}{l}0.15 \\
0.36\end{array}$ & $-3.10^{\star \star \star}$ \\
\hline Number of cases & 41 & 1667 & \\
\hline
\end{tabular}

$\star * \star, * \star \star$ denote statistical significance at an error level of 10 , 5, and 1 percent. 
Table IV

Descriptive statistics (Part IV): Male vs. female nascent entrepreneurs

\begin{tabular}{|c|c|c|c|}
\hline & $\begin{array}{c}\text { Male nascent } \\
\text { entrepreneur } \\
\text { Mean } \\
\text { Std. Dev. }\end{array}$ & $\begin{array}{l}\text { Female nascent } \\
\text { entrepreneur } \\
\text { Mean } \\
\text { Std. Dev. }\end{array}$ & $\begin{array}{l}\text { Test of } \mathrm{H}_{0}: \\
\text { Difference } \\
\text { in means }=0 \\
(t-\text { value })\end{array}$ \\
\hline Age (years) & 35.26 & 41.85 & $4.17^{\star \star \star}$ \\
\hline Age (squared) & $\begin{array}{r}9.14 \\
1326.12 \\
686.11\end{array}$ & $\begin{array}{r}8.04 \\
1814.83 \\
675.19\end{array}$ & $3.83^{\star \star \star}$ \\
\hline Number of fields of experience & $\begin{array}{l}4.40 \\
3.64\end{array}$ & $\begin{array}{l}3.51 \\
2.51\end{array}$ & -1.62 \\
\hline Number of professional degrees & $\begin{array}{l}1.12 \\
0.53\end{array}$ & $\begin{array}{l}1.05 \\
0.55\end{array}$ & -0.71 \\
\hline $\begin{array}{l}\text { Fear of failure a reason not to start } \\
\text { an own business (dummy; } 1=\text { yes) }\end{array}$ & $\begin{array}{l}0.24 \\
0.43\end{array}$ & $\begin{array}{l}0.17 \\
0.38\end{array}$ & -0.95 \\
\hline $\begin{array}{c}\text { Role model (dummy; } 1=\text { at least one } \\
\text { self-employed in the family }\end{array}$ & $\begin{array}{l}0.59 \\
0.49\end{array}$ & $\begin{array}{l}0.63 \\
0.49\end{array}$ & $0.44 t$ \\
\hline Small firm (dummy; $1-20$ employees) & $\begin{array}{l}0.38 \\
0.49\end{array}$ & $\begin{array}{l}0.56 \\
0.50\end{array}$ & $1.88^{\star}$ \\
\hline Young firm (dummm; up to 10 years old) & $\begin{array}{l}0.37 \\
0.49\end{array}$ & $\begin{array}{l}0.49 \\
0.51\end{array}$ & 1.21 \\
\hline Young firm * small firm (interaction term) & $\begin{array}{l}0.27 \\
0.45\end{array}$ & $\begin{array}{l}0.39 \\
0.49\end{array}$ & 1.28 \\
\hline Number of cases & 91 & 41 & \\
\hline
\end{tabular}

* ${ }^{*}, * * *$ denote statistical significance at an error level of 10, 5, and 1 percent. 
Table V

Rare events logit estimates for being a nascent entrepreneur

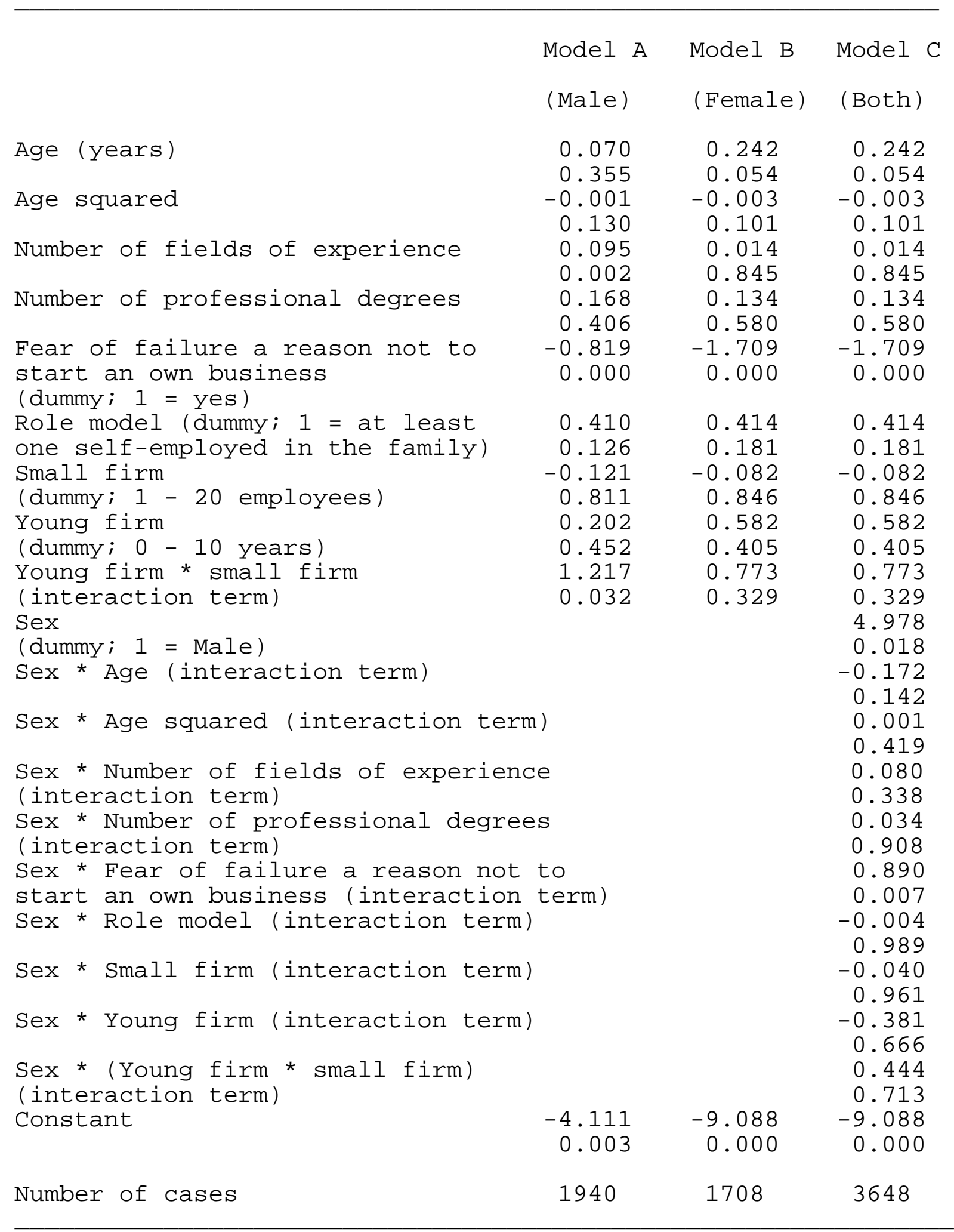

Note: Prob-values are reported below the estimated coefficients 
Table VI

Comparison of females and matched males

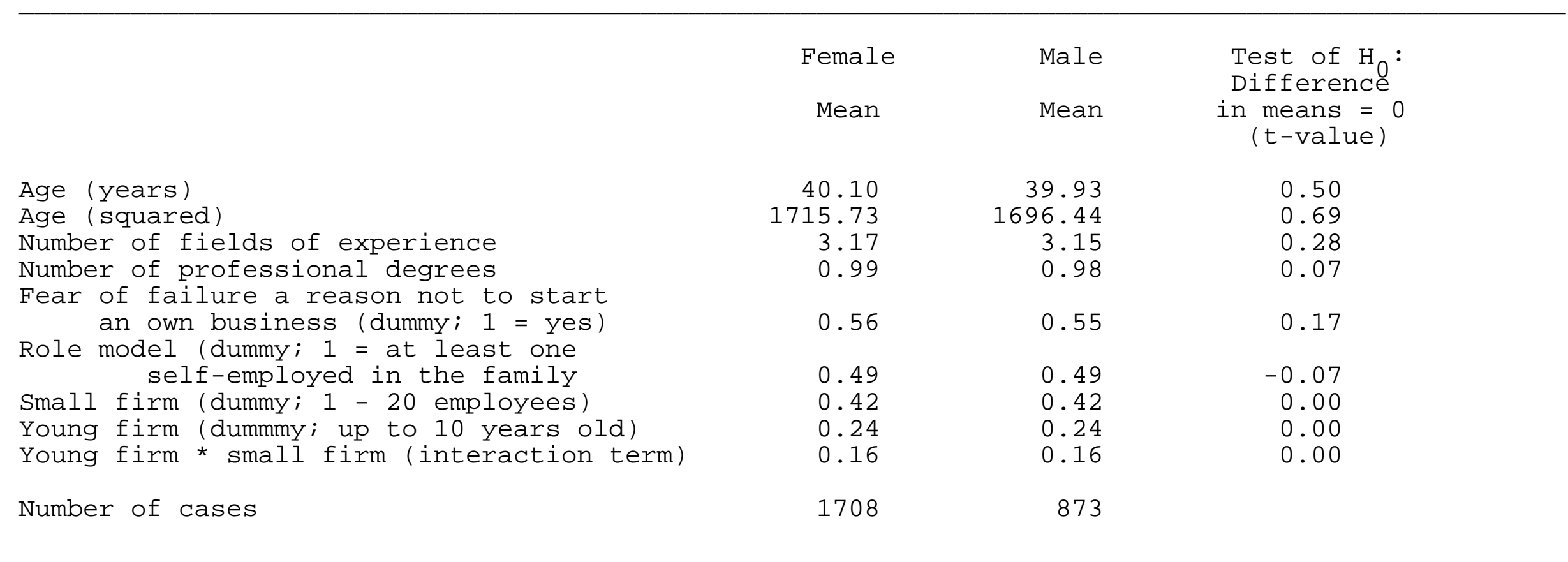


